\title{
Hepatitis Delta: Epidemiology, Diagnosis and Management 36 Years After Discovery
}

\author{
Mazen Noureddin • Robert Gish
}

Published online: 30 November 2013

(C) The Author(s) 2014. This article is published with open access at Springerlink.com

\begin{abstract}
With recent studies showing increased prevalence of hepatitis delta (HDV) even in the US, Australia, and some countries in Europe, and very high prevalence in endemic regions, HDV infection is far from being a disappearing disease. Although immigrants from endemic countries have been shown to have increased risk, studies have clearly shown that the disease is not solely appearing in traditional high-risk groups. Recent studies provide increasing evidence that sexual transmission may be an important factor in HDV infection spread. Based on the totality of evidence showing increased disease progression and substantially increased risk of cirrhosis in HDV-infected CHB patients, and the current studies showing higher than expected prevalence, it is time to call for HDV screening of all CHB patients. HDV viral load detection and measurement should be considered in all patients whether or not they are anti-HDV-positive. With universal screening of CHB patients for HDV, earlier diagnosis and consideration of treatment would be possible. Current treatment of HDV is IFN-based therapy with or without HBV antivirals, but current research indicates the possibility
\end{abstract}

This article is part of the Topical Collection on Liver

\section{Noureddin $(\bowtie)$}

Division of Gastroenterology and Hepatology, Keck School of Medicine, University of Southern California, 2011 Zonal Avenue, HMR 101, Los Angeles, CA 90033, USA

e-mail: Noureddi@med.usc.edu

R. Gish

Robert G. Gish Consultants, LLC, San Diego, CA, USA

R. Gish

St. Joseph's Hospital and Medical Center, Phoenix, AZ, USA

R. Gish $(\bowtie)$

University of Nevada, Las Vegas, 6022 La Jolla Mesa Drive, San

Diego, CA 92037, USA

e-mail: rgish@rgishmdliverconsults.com that prenylation inhibitors, entry inhibitors, HBsAg release inhibitors, or other therapies currently in the pipeline may provide more effective therapy in the future. In addition, universal screening would serve the important public health goal of allowing patients to be educated on their status and on the need for HDV-negative patients to protect themselves against superinfection and for HDV-infected patients to protect against transmission to others. Further studies and global awareness of HDV infection are needed.

Keywords Hepatitis - RNA - Chronic hepatitis · Hepatitis delta virus $\cdot$ Cirrhosis $\cdot$ Interferon-alpha

\begin{tabular}{|c|c|}
\hline \multicolumn{2}{|c|}{ Abbreviations } \\
\hline BEA & Baseline Event-Anticipation \\
\hline $\mathrm{CHB}$ & cChronic hepatitis B \\
\hline chol-siRNA & cCholesterol-conjugated siRNA \\
\hline HBsAg & hHepatitis B surface antigen \\
\hline $\mathrm{HBV}$ & hHepatitis B virus \\
\hline $\mathrm{HCC}$ & hHepatocellular carcinoma \\
\hline $\mathrm{HDV}$ & Hepatitis Delta virus \\
\hline NAG-MLP & $\begin{array}{l}\mathrm{N} \text {-acetylgalactosamine-conjugated } \\
\text { melittin-like peptide }\end{array}$ \\
\hline NAP & nNucleic acid-based amphipathic polymer \\
\hline Peg-IFN & pPegylated interferon \\
\hline qRT-PCR & $\begin{array}{l}\text { qQuantitative reverse transcription- } \\
\text { polymerase chain reaction }\end{array}$ \\
\hline RNAi & RNA interference \\
\hline
\end{tabular}

\section{Introduction}

Hepatitis delta virus (HDV) was first discovered in 1977 by Mario Rizzetto in Turin, Italy [1]. Collaboration between 
Turin and US scientists on experiments in chimps demonstrated that the delta antigen requires $\mathrm{HBV}$ for its ability to infect hepatocytes [2-4]. HDV is the smallest human RNA virus with a small circular RNA genome of approximately 1,700 bases; the genome is single-stranded negative sense and forms a covalently closed circle [5]. Because of a large amount of base pairing, the viral RNA takes on a rod-like structure. The RNA then encodes a protein called the delta antigen, which is subsequently encased in an envelope embedded with hepatitis B surface antigen (HBsAg) [5]. HDV infection is significant because, although it suppresses hepatitis B virus (HBV) replication, it can cause severe liver disease that may include fulminant liver failure and rapid progression to cirrhosis and hepatic decompensation, as well as an increased risk of liver cancer. Since HDV can only cause infection in the presence of $\mathrm{HBV}$, it was thought that the widespread introduction of HBV vaccine would ultimately result in decreased prevalence of HDV. However, current studies have shown that ongoing high prevalence remains in many parts of the world.

\section{Prevalence}

It was long ago established that HDV is found throughout the world, with higher prevalence in countries with populations of low socioeconomic status in Africa and South America, as well as in Turkey, Mongolia, southern Italy, and the Soviet Union [6]. HDV antibodies were found in up to $30 \%$ of chronic hepatitis $\mathrm{B}(\mathrm{CHB})$ patients in some of these countries [7]. On the other hand, there was a lower prevalence in $\mathrm{CHB}$ patients in northern Europe and North America, with HDV infection thought to be mainly restricted to intravenous drug users $[4,7]$. In the second decade after discovery, there was a decrease in prevalence of HDV which was thought to be mainly the result of the implementation of the HBV vaccine [8]. This led to decreased awareness and testing for HDV which further contributed to the perception that the virus was on its way to being eradicated [8]. Unfortunately, recent studies have shown the contrary.

In the United States, a recent study found that $8 \%$ of $\mathrm{CHB}$ patients in northern California were coinfected with HDV [9••]. Interestingly, $73 \%$ of the coinfected patients had cirrhosis compared to $17 \%$ of patients who were only HBV infected. In addition, $63 \%$ of these patients were born in North America and only $26 \%$ reported past IV drug use, showing that the disease is not solely appearing in immigrants and drug users. These findings clearly emphasize the importance of HDV screening of all CHB patients, not just those with established risk factors or cirrhosis. However, drug use is clearly still a major risk factor, with a study from Baltimore showing $50 \%$ HDV coinfection in CHB patients who are IV drug users [10].
Worldwide, it is estimated that 15-20 million people are HDV infected, with widely varying prevalence, depending on the region [7, 11]. The highest prevalence is seen in the Mediterranean basin, the Middle East, central and northern Asia, western and central Africa, the Amazonian basin (Brazil, Peru, Venezuela, and Colombia), the Pacific islands [12], and Vietnam [13]. In a recent study in the western Brazilian Amazon region, $41.9 \%$ of $\mathrm{HBsAg}$-positive patients were found to be coinfected with HDV, with prevalence over $60 \%$ among individuals aged 20-39 years [14]. The higher prevalence in this age group suggests the likelihood of sexual transmission. In a 2013 study from West Africa (Mauritania), it was found that up to $30 \%$ of CHB patients had anti-HDV antibodies [15]. Among these, 62.2\% were HDV-RNApositive. A recent study from the Middle East showed that, in Zahedan, Iran, $17 \%$ of CHB patients were positive for antiHDV antibodies [16]. A recent meta-analysis showed that $14.8 \%$ of asymptomatic HBsAg-positive patients in the eastern Mediterranean region are coinfected with HDV and that cirrhosis is common in this group [17]. A recent study in Vietnam showed HDV prevalence of $10.7 \%$ in CHB patients [13], a prevalence much higher than expected since previous studies had shown either very low levels of HDV infection in Vietnamese CHB patients [18] or none at all [19]. These studies confirm the continuing high prevalence of HDV infection in the Amazonian basin, the Middle East, the eastern Mediterranean region, and western Africa, and show the unexpectedly high prevalence in Vietnam. At the other end of the prevalence scale, a recent report from Egypt showed that $4.7 \%$ of CHB patients are coinfected with HDV [20]. In a study in India which assessed $450 \mathrm{CHB}$ patients for coinfection with HIV or HDV, it was found that $4.8 \%$ were $\mathrm{HBV} /$ HDV-coinfected, while only $1.5 \%$ were HIV/HBVcoinfected and $0.8 \%$ were $\mathrm{HBV} / \mathrm{HDV} / \mathrm{HIV}$-tri-infected [21]. However, HBV/HDV coinfection was substantially higher $(45.8 \%)$ in patients aged $21-40$ years old. Again, the higher prevalence in this age group suggests that the transmission of HDV could be due to sexual transmission.

In Europe, where HDV had been thought to be decreasing, studies in 2013 showed a trend toward increasing prevalence. In a large prospective Greek study which has followed 4,673 CHB patients from 1997 to the present, of the 2,137 patients who have been screened for HDV, $4.2 \%$ were found to be anti-HDV-positive, with substantially greater prevalence seen in immigrants $(7.5 \%)$ than in native Greeks $(2.8 \%)$. The study showed that HDV testing decreased substantially over time, dropping from $57 \%$ prior to 2003 to only $35.3 \%$ thereafter [22]. Within 2.3 years of follow-up, new HDV infection occurred in 2.2 adults and 8.7 children per 1,000 HBsAg-positive patients annually. A study from Belgium showed that $5.5 \%$ of CHB patients are HDV-coinfected, a prevalence that is higher than previously reported [23]. In London, the prevalence of HDV infection was found to be 
$2 \%$ among CHB patients [24]. The majority of HDV-infected patients were either IV drug users or immigrants. In comparison, other European countries were found to have substantially higher prevalence in some populations, with coinfection reported in $20.4 \%$ of CHB patients in Bucharest, Romania, and $20.9 \%$ of $1,220 \mathrm{CHB}$ immigrants from Equatorial Guinea living in Spain $[25,26]$.

Finally, an important Australian study found that of the 2, 314 Victoria residents tested for HDV infection from 2000 to 2009, $110(4.75 \%)$ were found to be HDV-infected [27]. Both the number of people testing positive and the number of tests conducted steadily increased between 2005 and 2009. The majority of cases were immigrants $(71.4 \%)$ and male $(77 \%)$. The investigators concluded that their findings emphasize the need for routine HDV testing of all CHB patients. We agree, and believe that, since HDV coinfection results in worse disease, including cirrhosis at younger age, the continuing high prevalence in many countries, and trend toward increasing prevalence in some parts of the world, these clearly point to the need to revise screening guidelines to call for HDV screening in all CHB patients. With multiple studies showing particularly high prevalence in immigrants from endemic countries, they should be considered as being at particularly high risk of being infected.

\section{Clinical Course}

The transmission of HDV can occur sexually (via semen or vaginal secretions), through blood (needle stick injuries, injection drug use, and transfusions), and perinatally. Recent studies provide increasing evidence that sexual transmission may be a more important factor in the spread of the disease than has previously been appreciated. The studies discussed above that found substantially higher prevalence of HDV coinfection in patients aged $20-39$ years ( $60 \%$ vs. an overall prevalence of $41.9 \%$ ) [14] and in $21-40$ year olds ( $45.8 \%$ vs. an overall prevalence of $4.8 \%$ ) [21] highlight the importance of sexual transmission and point to the need to first screen patients and then educate HDV-negative patients about the need for protection against superinfection and HDV-infected patients about the need to protect against transmission to others.

HDV can be transmitted only in the existence of concomitant HBV infection as one of two patterns, simultaneous HBV/HDV infection (coinfection) or HDV infection of an individual already chronically infected with HBV (superinfection). The coinfection pattern ranges from mild to severe or fulminant hepatitis [28]. Coinfection is usually selflimited, with $20 \%$ of cases progressing to cirrhosis. However, coinfection can lead to more severe fulminant hepatitis compared to superinfection [29]. Superinfection may present as exacerbation of disease in previously asymptomatic CHB patients, worsening of disease in CHB patients, or as acute hepatitis [29]. Superinfection is usually confirmed with positive HDV antibodies and negative IgM anti-HBc [29]. Chronic hepatitis $\mathrm{D}$ is acquired in $90 \%$ of superinfection cases and leads to cirrhosis in 5-10 years in $70 \%$ of the patients. Cirrhosis incidence is three times higher with HDV infection than with HBV monoinfection [29]. Cirrhosis may continue for many years, but a high percentage of patients will decompensate, develop hepatocellular carcinoma (HCC), and/or receive liver transplantation [30]. HCC association with chronic HDV is still controversial, with some studies showing up to a three-fold increase in risk and others showing no increase [30]. Pathogenicity can influence outcome in HDV infection and may vary between genotypes [31]. At least 8 genotypes of HDV have been described. Genotype I has been found in the United States, Europe, the Middle East, North America, and North Africa. Genotype II has been found in the Far East, Genotype III in South America, and Genotypes IV-VIII in Africa [31].

\section{Diagnosis}

With the high prevalence in many countries already discussed, including the surprisingly high prevalence in the US despite its longstanding HBV vaccination programs, and the trends toward increasing prevalence in some parts of the world, it seems more than reasonable to advocate for all CHB patients to be screened for HDV infection. With multiple studies showing particularly high prevalence in immigrants from endemic countries, they should be considered as being at particularly high risk of being infected, and consideration should be given to the development of programs to reach this population. There should absolutely be testing of all members of high-risk groups, including injection drug users, men who have sex with men, hemodialysis patients, anyone who has sexual contact with confirmed HDV-infected persons, and health-care and public safety workers. Patients with chronic HBV who experience clinical deterioration should also be tested [32].

HDV antigen can be measured; however, it is only transiently detectable in serum. The detection of HDV antibodies in HBsAg-positive patients is usually the initial step in the diagnosis of HDV; however, these antibodies can be falsely negative. Recently, there has been an emphasis on testing for HDV RNA viral load as more laboratories have gained experience in measuring it. To date, this method has mostly been done in academic centers.

It is not yet commercially available in the US, although the PCR test is becoming more available in some other countries $\left[33^{\bullet}, 34\right]$. In the US, a one-step TaqMan quantitative reverse transcription polymerase chain reaction (qRT-PCR) assay has been developed for detection of HDV RNA, which has been 
found to be highly reliable and accurate in detecting viral load [35]. It is likely that viral load testing will be available soon in the US in commercial laboratories, and, in the meantime, all efforts should be made to send samples, especially with suspect populations, to laboratories experienced in measuring viral load. Any physician or associated medical personnel can submit specimens to the CDC for HDV testing if the person is suspected of having HDV. The specimens should be packaged in accordance with the CDC requirements for shipping biological specimens (http://www.cdc.gov/hepatitis/ HEV/PDFs/HRL_PCRSampleHndlgShpg_20080615.pdf) and must be accompanied by the form from this link completed in its entirety: http://www.cdc.gov/hepatitis/HDV/ index.htm.

In HDV-positive patients, it is critical to distinguish acute HDV and HBV infection (coinfection) from HDV superinfection in CHB patients, since the prognosis and management are different. Acute infection with HDV concomitant with acute infection with HBV usually appears first as IgM anti-HDV and then converts to IgG anti-HDV; HDV RNA levels reach high levels in the serum. HBV IgM anti-HBc will also be found to be positive in this acute HDV/HBV coinfection. In superinfection, HDV antibodies appear early as IgM, followed by IgG anti-HDV, whereas anti-HBc is IgG only. Both HDV and HBV antibodies may increase in superinfection as the HDV disease progresses to chronicity, and may be present in high titers along with positive HDV RNA. Finally, a Baseline Event-Anticipation (BEA) score has been developed to predict the risk of development of liver-related complications (decompensation, hepatocellular carcinoma, liver transplantation, and/or death) in chronic HDV patients [36॰]. This easy to apply clinical instrument uses age, gender, region of origin, INR, platelet number, and bilirubin to calculate the score. Factors associated with a poor long-term outcome include age above 40 , male sex, low platelet counts, high bilirubin, elevated INR, and southeast Mediterranean origin.

\section{Treatment}

To date, the unique HDV replication cycle and its association with HBV have led to difficulties in treatment regimens and inadequate response rates. The ultimate approach for eradication of HDV is the clearance of HBsAg, not just sustained HDV virological response (negative HDV RNA 6 months after stopping treatment) [37]. If HBsAg remains positive, HDV remains infectious, even if the HBV or HDV viral titers are low. This has led to the concept that eradication of HBsAg might also clear HDV infection. However, despite inhibition of HBV replication and, in some cases, HBsAg clearance, the clearance of HDV has not been seen when oral antivirals against HBV were used alone. Lamivudine, ribavirin, famciclovir, adefovir, and entecavir have shown little or no effect when used alone to treat HDV, regardless of the duration of treatment [38-42].

Interferon-alpha is the only therapy that has been shown to be at least somewhat effective for treatment of HDV (Table 1), leading to virological, biochemical, and histological response in some patients. Weekly injection of PEG-IFN-a is currently used for 12-18 months. A 2013 review concluded that recent trials have shown HDV SVRs in 25-30\% of patients treated with pegylated interferons (Peg-IFN) [43]. However, in one of the few trials with truly long-term follow-up, Heidrich and colleagues found that even in patients who are HDV-RNAnegative 6 months after Peg-IFN-based treatment, late relapses may occur [44••]. In their initial study, Peg-IFN alfa2a treatment for 48 weeks, with or without adefovir, resulted in $28 \%$ of the patients having undetectable HDV-RNA 6 months post-treatment [42]. Long-term follow-up data were available for 37 of the 60 patients treated with Peg-IFN, with a median time of follow-up of approximately 4 years. Of the 16 patients entering the follow-up study who were HDV-RNAnegative 6 months after treatment, half ( 8 individuals) tested HDV-RNA-positive at least once during further follow-up, leading the investigators to call for close monitoring of patients post-Peg-IFN therapy, even in patients who are HDVRNA-negative 6 months after therapy completion [44••].

HDV may relapse if HBsAg remains positive [40]. In a long ago trial of IFN-alfa-2a therapy that compared no treatment to high-dose ( 9 million units) and low-dose ( 3 million units) IFN, given 3 times a week for 48 weeks, $50 \%$ of the high-dose group had a complete response defined by biochemical response (normalization of ALT) in addition to virological response (negative HDV levels at the end of the treatment), compared to no complete response in any of those in the low-dose or no-treatment groups. Although sustained clearance of HDV RNA was not maintained in the high-dose group following cessation of therapy, a long-term follow-up study (up to 12 years) demonstrated significantly improved survival and liver histology [45]. More recently, Peg-IFN has been increasingly used because of its longer half-life, which allows once weekly dosing. Although no head-to-head comparison trials have been carried out, two major reviews have not been able to definitively show that either type of IFN therapy is superior to the other. Although one recent systematic review of randomized trials found that 1 year of high-dose interferon-alpha monotherapy achieved higher levels of undetectable HDV RNA and normalization of ALT at the end of treatment when compared with Peg-IFN-alpha monotherapy (RR 4.14; $95 \%$ CI 1.00-17.14), levels of HDV RNA suppression 24 weeks after the end of therapy were not significantly different [46]. Another systematic review comparing standard and Peg-IFN-alpha found pooled sustained virologic response rates of 19 and $29 \%$ of patients, respectively [47]. However, the investigators were unable to reach definitive conclusions on superiority due to the variation in trial designs 
Table 1 Outcomes of interferon therapy

\begin{tabular}{|c|c|c|c|c|c|c|}
\hline Study & Type & $n$ & Treatment regimen & Duration & $\begin{array}{l}\text { Treatment response } \\
\text { definition }\end{array}$ & Treatment outcome \\
\hline $\begin{array}{l}\text { Farci et al. } \\
\quad[45]\end{array}$ & Randomized & 42 & $\begin{array}{l}\text { IFN a-2a (9M) (14) } \\
\text { vs. } \\
\text { IFN alpha-2a (3 M) } \\
\quad(14) \\
\text { vs. } \\
\text { No therapy (14) }\end{array}$ & 48 weeks & $\begin{array}{l}\text { At EOT: } \\
\text { Biochemical (ALT) } \\
\text { Virological (HDV } \\
\text { RNA eradication) } \\
\text { Complete (ALT + } \\
\text { RNA) }\end{array}$ & $\begin{array}{l}\text { Biochemical: } \\
\text { High dose }(71 \%) \\
\text { Low dose }(29 \%) \\
\text { Controls }(8 \%) \\
\text { Virological: } \\
\text { High dose }(71 \%) \\
\text { Low dose }(36 \%) \\
\text { Controls }(0 \%) \\
\text { Complete: } \\
\text { High dose }(50 \%) \\
\text { Low dose }(21 \%) \\
\text { Complete }(0 \%)\end{array}$ \\
\hline $\begin{array}{l}\text { Yuradaydin } \\
\text { C et al. } \\
{[61]}\end{array}$ & $\begin{array}{l}\text { Non- } \\
\text { randomized }\end{array}$ & 39 & $\begin{array}{l}\text { IFN a-2a (9M) } \\
\text { Vs. } \\
\text { Lamivudine } \\
\quad 100 \mathrm{mg} \text { /day } \\
\text { vs. } \\
2 \text { months } \\
\text { lamivudine } \\
\text { followed by } \\
\text { IFN a-2a+ } \\
\text { Lamivudine }\end{array}$ & 12 months & $\begin{array}{l}\text { At EOT: } \\
\text { Biochemical (ALT) } \\
\text { Virological (HDV } \\
\text { RNA eradication) } \\
\text { Histological } \\
\text { SVR (6 months } \\
\quad \text { post-treatment) }\end{array}$ & $\begin{array}{l}\text { Combination treatment was not superior } \\
\text { to IFN monotherapy. }\end{array}$ \\
\hline $\begin{array}{l}\text { Yuradaydin } \\
\text { C et al. } \\
{[62]}\end{array}$ & $\begin{array}{l}\text { Non- } \\
\quad \text { randomized }\end{array}$ & 23 & $\begin{array}{l}10 \mathrm{MU} \text { interferon } \\
\text { alpha } 2 \mathrm{~b}, \\
\text { thrice weekly }\end{array}$ & 24 months & $\begin{array}{l}\text { At EOT and } \\
6 \text { months post- } \\
\text { treatment: } \\
\text { Biochemical (ALT) } \\
\text { Virological (HDV } \\
\text { RNA eradication) } \\
\text { Histological }\end{array}$ & $\begin{array}{l}\text { Biochemical (ALT): } 47 \% \text { had a biochemical response } \\
\text { but only } 2(13 \%) \text { had normal ALT after follow-up } \\
\text { Virological: observed in } 40 \% \text { patients at EOT } \\
\text { and } 13.3 \% \text { at follow-up. } \\
\text { Histological: observed in } 53 \% \text { patients } \\
2 \text { years of treatment does not increase SVR } \\
\text { over } 1 \text { year treatment. }\end{array}$ \\
\hline $\begin{array}{r}\text { Castelnau C } \\
\text { et al. [63] }\end{array}$ & $\begin{array}{l}\text { Non- } \\
\text { randomized }\end{array}$ & 14 & $\begin{array}{l}\text { PEG-IFN alpha-2b } \\
\quad(1.5 \mu \mathrm{g} / \mathrm{kg} / \text { week })\end{array}$ & 12 months & SVR & $\begin{array}{l}\text { Virological: } \\
\text { EOT: } 8 \text { patients }(57 \%) \\
\text { SVR: } 6 \text { patients }(43 \%) \\
\text { Biochemical: } \\
8 \text { patients }(57 \%) \text { were responders at EOT }\end{array}$ \\
\hline $\begin{array}{l}\text { Niro GA } \\
\text { et al. [48] }\end{array}$ & $\begin{array}{l}\text { Non- } \\
\quad \text { randomized }\end{array}$ & 38 & $\begin{array}{l}\text { PEG-IFN alpha-2b } \\
\text { monotherapy } \\
\text { (72 weeks) } \\
\text { PEG-IFN alpha 2b+ } \\
\text { RBV } \\
\text { (48 weeks) } \\
\text { followed by } \\
\text { PEG-IFN } \\
\text { monotherapy } \\
\text { (24 weeks) }\end{array}$ & 72 weeks & & $\begin{array}{l}\text { Virological: } \\
\text { PEG IFN: }(19 \%) \\
\text { PEG IFN+RBV: }(9 \%) \\
\text { Biochemical: } \\
\text { PEG IFN: }(37.5 \%) \\
\text { PEG IFN+RBV: }(41 \%)\end{array}$ \\
\hline $\begin{array}{r}\text { Wedemeyer } \\
\text { et al. [42] }\end{array}$ & $\mathrm{RCT}$ & 90 & $\begin{array}{l}\text { PegIFN alfa- } 2 \mathrm{a}+ \\
\quad \text { adefovir } \\
\text { vs. } \\
\text { PegIFN alfa-2a+ } \\
\quad \text { placebo } \\
\text { vs. } \\
\text { Adefovir alone }\end{array}$ & 48 weeks & $\begin{array}{l}\text { Clearance of HDV } \\
\text { RNA } \\
\text { Normalization } \\
\quad \text { of ALT } \\
\text { Decline in HBsAg } \\
\text { levels }\end{array}$ & $\begin{array}{l}\text { EOT: HDV RNA was negative in } 23 \% \text { in the } \\
\text { first group, } 24 \% \text { in the second, and none in the third } \\
\text { SVR: } 28 \% \text { in the } 1 \text { st and } 2 \text { nd groups and none } \\
\text { in the } 3 \text { rd group. } \\
\text { A decline in HBsAg levels of more than } 1 \\
\log (10) \mathrm{IU} / \mathrm{mL} \text { observed in } 10 / 31 \text { patients in the first } \\
\text { group, } 2 / 29 \text { in the second, and none in the third }\end{array}$ \\
\hline
\end{tabular}

involving standard IFN and the small number of patients involved. In other studies, the combination of Peg-IFN with ribavirin or with adefovir has been compared to treatment with Peg-IFN alone [42, 48]. The combinations yielded no difference in SVR rate, although the combination of Peg-IFN and adefovir resulted in increased decline in HBsAg levels. Extending the duration of Peg-IFN therapy has shown no effect on response rate [49]. In a study from Turkey, $32 \%$ of patients with advanced chronic liver disease achieved virological response with Peg-IFN treatment and there was no significant 
difference in treatment response between patients with advanced and non-advanced chronic liver disease [50]. Acute HDV hepatitis has been more challenging to treat. Patients with fulminant hepatitis have had no response to IFN-alpha therapy, and liver transplant is the only option for fulminant hepatic failure resulting from coinfection or superinfection with HDV [51].

\section{Future Treatment}

There are several current areas of research that may ultimately lead to important HDV treatment advances. Prenylation of the last four amino acids on the large-HDAg (the so-called CXXX box) is important for the interaction of HDV antigen with HBsAg $[43,52,53]$. Many small-molecule inhibitors of protein farnesyltransferase (which plays a role in prenylation) have been developed. These molecules compete with CXXX peptide substrates or with farnesyl diphosphate [43]. Both in vitro and in vivo studies have demonstrated that inhibition of prenylation results in clearance of HDV infection. Currently, the National Institutes of Health is enrolling HDV patients in a double-blinded, randomized, placebo-controlled trial to investigate the effectiveness of 4 weeks of treatment with the prenylation inhibitor lonafarnib, an oral farnesyltransferase inhibitor, with post-therapy follow up for a total of 6 months to assess for a sustained virological response (http://www. clinicaltrials.gov/ct2/show/NCT01495585?term= lonafarnib\&rank=11).

Myclurdex, an HBV entry inhibitor, may also hinder the establishment of HDV infection by breaking the cycle of hepatocyte infection and possibly re-infection [54]. REP 9AC is a nucleic acid-based amphipathic polymer (NAP) which inhibits the release of $\mathrm{HBsAg}$ from infected hepatocytes. REP 9AC is currently being evaluated in patients with chronic HBV in a proof-ofconcept clinical trial. Interim data showed that seven out of eight patients treated with REP 9AC cleared HBsAg or had only residual levels $[55,56]$. Clearance of HBsAg and development of anti-HBs occurred as early as 7 days and no later than 32 weeks. Since HDV requires $\mathrm{HBsAg}$ for complete replication and transmission, REP 9AC might ultimately become an important new treatment tool.

New research on RNA interference (RNAi)-based therapies shows that they may also have the potential to treat HBV/ HDV coinfection. In recent proof-of-concept studies, it was shown that, in transient and transgenic mouse models, coinjection of a hepatocyte-targeted, N-acetylgalactosamineconjugated melittin-like peptide (NAG-MLP) with a livertropic cholesterol-conjugated siRNA (chol-siRNA) targeting conserved HBV sequences yielded multilog repression of viral RNA, proteins, and viral DNA [57]. With production of HBsAg blocked via RNA interference, HDV viral release might be decreased or prevented, potentially allowing immune control to overtake viral replication and effect viral clearance [58-60]. Finally, in the same way that we can currently use changes in levels of cytokines such as IP10 to monitor patients' responses to standard interferon therapy, we may in future be able to map cytokine levels in order to monitor responses to new immunotherapy agents used as treatments for HBV and HDV, such as lambda interferon and TLR7 agonists.

\section{Conclusion}

HDV infection is far from being a disappearing disease. Studies have shown increased prevalence even in developed countries, including the US, Australia, and some countries in Europe, and very high prevalence in endemic regions, despite the implementation of widespread HBV vaccination. Immigrants from endemic countries have been shown to have increased risk. Recent studies provide increasing evidence that sexual transmission may be an important factor in the spread of HDV infection. Based on the totality of evidence showing increased disease progression and substantially increased risk of cirrhosis in CHB patients who are also infected with HDV, and the current studies showing higher than expected prevalence, it is time to call for HDV screening of all CHB patients. HDV viral load detection and measurement should be considered in all patients whether or not they are anti-HDV-positive. With universal screening of CHB patients for HDV, earlier diagnosis and consideration of treatment would be possible. Current treatment of HDV is IFN-based therapy with or without HBV antivirals, but current research indicates the possibility that prenylation inhibitors, entry inhibitors, HBsAg release inhibitors, or the other therapies currently in the pipeline discussed here may provide more effective therapy in the future. In addition, universal screening would serve the important public health goal of allowing patients to be educated on their status and on the need for HDV-negative patients to protect themselves against superinfection, and for HDV-infected patients to protect against transmission to others. Further studies and global awareness of HDV infection are needed.

\section{Compliance with Ethics Guidelines}

Conflict of Interest Dr. Gish and Dr. Noureddin have no conflicts of interest.

Human and Animal Rights and Informed Consent This article does not contain any studies with human or animal subjects performed by the author. 
Open Access This article is distributed under the terms of the Creative Commons Attribution License which permits any use, distribution, and reproduction in any medium, provided the original author(s) and the source are credited.

\section{References}

Papers of particular interest, published recently, have been highlighted as:

- Of importance

•- Of major importance

1. Rizzetto M, Canese MG, Arico S, et al. Immunofluorescence detection of new antigen-antibody system (delta/anti-delta) associated to hepatitis B virus in liver and in serum of HBsAg carriers. Gut. 1977;18:997-1003.

2. Rizzetto M, Canese MG, Gerin JL, et al. Transmission of the hepatitis B virus-associated delta antigen to chimpanzees. J Infect Dis. 1980;141:590-602.

3. Rizzetto M, Hoyer B, Canese MG, et al. delta Agent: association of delta antigen with hepatitis B surface antigen and RNA in serum of delta-infected chimpanzees. Proc Natl Acad Sci U S A. 1980;77: 6124-8.

4. Rizzetto M, Purcell RH, Gerin JL. Epidemiology of HBV-associated delta agent: geographical distribution of anti-delta and prevalence in polytransfused HBsAg carriers. Lancet. 1980;1:1215-8.

5. Flores R, Ruiz-Ruiz S, Serra P. Viroids and hepatitis delta virus. Semin Liver Dis. 2012;32:201-10.

6. Rizzetto M, Ponzetto A, Forzani I. Hepatitis delta virus as a global health problem. Vaccine. 1990;8(Suppl):S10-4. discussion S21-13.

7. Wedemeyer H, Manns MP. Epidemiology, pathogenesis and management of hepatitis D: update and challenges ahead. Nat Rev Gastroenterol Hepatol. 2010;7:31-40.

8. Rizzetto M, Ciancio A. Epidemiology of hepatitis D. Semin Liver Dis. 2012;32:211-9.

9. - Gish RG, Yi DH, Kane S, et al. Coinfection with Hepatitis B and D: epidemiology, prevalence and disease in patients in Northern California. J Gastroenterol Hepatol. 2013;28(9):1521-5. This is the first epidemiological study of hepatitis delta in the US in $>10$ years; it provides data from a large patient-based population with a multitude of risk factors. The higher than expected prevalence supports revising screening guidelines to advocate for all patients with $H B V$ to be screened for HDVin order both to give the individual patient important information related to the possible need for treatment, and to support the public health goal of reducing transmission by educating $\mathrm{HDV}$ negative patients about the need for protection against superinfection and HDV-infected patients about the need to protect against transmission to others.

10. Kucirka LM, Farzadegan H, Feld JJ, et al. Prevalence, correlates, and viral dynamics of hepatitis delta among injection drug users. J Infect Dis. 2010;202:845-52.

11. Stroffolini T, Almasio PL, Sagnelli E, et al. Evolving clinical landscape of chronic hepatitis B: a multicenter Italian study. J Med Virol. 2009;81:1999-2006.

12. Alvarado-Mora MV, Locarnini S, Rizzetto M, et al. An update on HDV: virology, pathogenesis and treatment. Antivir Ther. 2013;18:541-8.

13. Dunford L, Carr MJ, Dean J, et al. A multicentre molecular analysis of hepatitis B and blood-borne virus coinfections in Viet Nam. PloS One. 2012;7:e39027.

14. Braga WS, Castilho Mda C, Borges FG, et al. Hepatitis D virus infection in the Western Brazilian Amazon - far from a vanishing disease. Rev Soc Bras Med Trop. 2012;45:691-5.
15. Lunel-Fabiani F, Mansour W, Amar AO, et al. Impact of hepatitis B and delta virus co-infection on liver disease in Mauritania: A cross sectional study. J Infect. 2013;67(5):448-57.

16. Bakhshipour A, Mashhadi M, Mohammadi M, et al. Seroprevalence and risk factors of hepatitis delta virus in chronic hepatitis B virus infection in Zahedan. Acta Med Iran. 2013;51:260-4.

17. Amini N, Alavian SM, Kabir A, et al. Prevalence of hepatitis d in the eastern mediterranean region: systematic review and meta analysis. Hepat Mon. 2013;13:e8210.

18. Nguyen VT, McLaws ML, Dore GJ. Highly endemic hepatitis B infection in rural Vietnam. J Gastroenterol Hepatol. 2007;22:2093-100.

19. Tran HT, Ushijima H, Quang VX, et al. Prevalence of hepatitis virus types $\mathrm{B}$ through $\mathrm{E}$ and genotypic distribution of $\mathrm{HBV}$ and $\mathrm{HCV}$ in Ho Chi Minh City, Vietnam. Hepatol Res. 2003;26:275-80.

20. Gomaa NI, Metwally LA, Nemr N, et al. Seroprevalence of HDV infection in HBsAg positive population in Ismailia, Egypt. Egypt $\mathrm{J}$ Immunol. 2013;20:23-8.

21. Saravanan S, Madhavan V, Velu V, et al. High prevalence of hepatitis delta virus among patients with chronic hepatitis B virus infection and HIV-1 in an intermediate hepatitis B virus endemic region. J Int Assoc Provid AIDS Care. 2013. doi:10.1177/ 2325957413488166.

22. Manesis EK, Vourli G, Dalekos G, et al. Prevalence and clinical course of hepatitis delta infection in Greece: a 13-year prospective study. J Hepatol. 2013;59(5):949-56.

23. Ho E, Deltenre P, Nkuize M, et al. Coinfection of hepatitis B and hepatitis delta virus in Belgium: a multicenter BASL study. Prospective epidemiology and comparison with HBV monoinfection. J Med Virol. 2013;85:1513-7.

24. William Tong CY, Asher R, Toby M, et al. A re-assessment of the epidemiology and patient characteristics of hepatitis D virus infection in inner city London. J Infect. 2013;66:521-7.

25. Popescu GA, Otelea D, Gavriliu LC, et al. Epidemiology of hepatitis D in patients infected with hepatitis B virus in bucharest: a cross-sectional study. J Med Virol. 2013;85:769-74.

26. Rivas P, Herrero MD, Poveda E, et al. Hepatitis B, C, and D and HIV infections among immigrants from Equatorial Guinea living in Spain. Am J Trop Med Hyg. 2013;88:789-94.

27. Shadur B, Maclachlan J, Cowie B. Hepatitis D virus in Victoria 2000-2009. Intern Med J. 2013;43(10):1081-7.

28. Farci P. Delta hepatitis: an update. J Hepatol. 2003;39 Suppl 1: S212-9.

29. Farci P, Niro GA. Clinical features of hepatitis D. Semin Liver Dis 2012;32:228-36.

30. Kew MC. Hepatitis viruses (other than hepatitis $B$ and $C$ viruses) as causes of hepatocellular carcinoma: an update. J Viral Hepat. 2013;20:149-57.

31. Olivero A, Smedile A. Hepatitis delta virus diagnosis. Semin Liver Dis. 2012;32:220-7.

32. Hughes SA, Wedemeyer H, Harrison PM. Hepatitis delta virus. Lancet. 2011;378:73-85.

33. - Katsoulidou A, Manesis E, Rokka C, et al. Development and assessment of a novel real-time PCR assay for quantitation of hepatitis D virus RNA to study viral kinetics in chronic hepatitis D. J Viral Hepat. 2013;20:256-62. This paper is important because we currently have no standardized PCR assays; a standardized assay is needed to be able to compare data outputs around the world andto cross-link studies.

34. Brichler S, Le Gal F, Butt A, et al. Commercial real-time reverse transcriptase PCR assays can underestimate or fail to quantify hepatitis delta virus viremia. Clin Gastroenterol Hepatol. 2013;11:734- 40.

35. Kodani M, Martin A, Mixson-Hayden T, et al. One-step real-time PCR assay for detection and quantitation of hepatitis D virus RNA. J Virol Methods. 2013;193:531-5.

36. - Calle Serrano B, Heidrich B, Homs M, et al. Development and evaluation of a Baseline Event-Anticipation (BEA)-score for 
hepatitis delta. Hepatology. 2011;54:444. This manuscript is important because the authors developed a sophisticated but very usable scoring system to assist with prognostication.

37. Yurdaydin C. Treatment of chronic delta hepatitis. Semin Liver Dis. 2012;32:237-44.

38. Niro GA, Ciancio A, Tillman HL, et al. Lamivudine therapy in chronic delta hepatitis: a multicentre randomized-controlled pilot study. Aliment Pharmacol Ther. 2005;22:227-32.

39. Garripoli A, Di Marco V, Cozzolongo R, et al. Ribavirin treatment for chronic hepatitis D: a pilot study. Liver. 1994;14:154-7.

40. Yurdaydin C, Bozkaya H, Gurel S, et al. Famciclovir treatment of chronic delta hepatitis. J Hepatol. 2002;37:266-71.

41. Lau DT, Doo E, Park Y, et al. Lamivudine for chronic delta hepatitis. Hepatology. 1999;30:546-9.

42. Wedemeyer H, Yurdaydin C, Dalekos GN, et al. Peginterferon plus adefovir versus either drug alone for hepatitis delta. N Engl J Med. 2011;364:322-31.

43. Heidrich B, Manns MP, Wedemeyer H. Treatment options for hepatitis delta virus infection. Curr Infect Dis Rep. 2013;15:31-8.

44. • Heidrich B, Yurdaydin C, Kabacam G, et al. Long-term followup after Peg-IFNa2a-based therapy of chronic hepatitis delta. J Hepatol. 2013;58:S20. This paper is very important because of the final data showing only a $15 \%$ long-term cure rate for $\mathrm{HDV}$, whereas historically there were publications that proposed cure rates of $30 \%$ or higher. The study provides clear evidence that we need new targeted therapies for $H D V$.

45. Farci P, Mandas A, Coiana A, et al. Treatment of chronic hepatitis D with interferon alfa-2a. N Engl J Med. 1994;330:88-94.

46. Lamers MH, Kirgiz OO, Heidrich B, et al. Interferon-alpha for patients with chronic hepatitis delta: a systematic review of randomized clinical trials. Antivir Ther. 2012;17:1029-37.

47. Alavian SM, Tabatabaei SV, Behnava B, et al. Standard and pegylated interferon therapy of HDV infection: a systematic review and meta- analysis. J Res Med Sci. 2012;17:967-74.

48. Niro GA, Ciancio A, Gaeta GB, et al. Pegylated interferon alpha-2b as monotherapy or in combination with ribavirin in chronic hepatitis delta. Hepatology. 2006;44:713-20.

49. Ormeci N, Bolukbas F, Erden E, et al. Pegylated interferon alfa-2B for chronic delta hepatitis: 12 versus 24 months. Hepatogastroenterology. 2011;58:1648-53.

50. Kabacam G, Dalekos GN, Cakaloglu Y, et al. Pegylated interferonbased treatment in patients with advanced liver disease due to chronic delta hepatitis. Turk J Gastroenterol. 2012;23:560-8.
51. Sanchez-Tapias JM, Mas A, Costa J, et al. Recombinant alpha 2cinterferon therapy in fulminant viral hepatitis. J Hepatol. 1987;5: 205-10.

52. Heller T, Hoofnagle JH. Denying the wolf access to sheep's clothing. J Clin Invest. 2003;112:319-21.

53. Glenn JS, Watson JA, Havel CM, et al. Identification of a prenylation site in delta virus large antigen. Science. 1992;256: 1331-3.

54. Lutgehetmann M, Mancke LV, Volz T, et al. Humanized chimeric uPA mouse model for the study of hepatitis B and $\mathrm{D}$ virus interactions and preclinical drug evaluation. Hepatology. 2012;55:685-94.

55. Mahtab MA, Bazinet M, Vaillant A. REP 9 AC: a potent HBsAg release inhibitor that can rapidly restore immunocompetence in patients with chronic hepatitis B. Hepatology. 2010;52:559A-60.

56. Mahtab MA, Bazinet M, Vaillant A. REP 9AC: a potent HBsAg release inhibitor that can rapidly restore immunocompetence in patients with chronic hepatitis B. The 61st Annual Meeting of the American Association for the Study of Liver Diseases; Boston, Massachusetts; Oct 29-Nov 2, 2010.

57. Wooddell CI, Rozema DB, Hossbach M, et al. Hepatocyte-targeted RNAi therapeutics for the treatment of chronic hepatitis B virus infection. Mol Ther. 2013;21:973-85.

58. Grabowski J, Yurdaydin C, Zachou K, et al. Hepatitis D virusspecific cytokine responses in patients with chronic hepatitis delta before and during interferon alfa-treatment. Liver Int. 2011;31: 1395-405.

59. Roethle PA, McFadden RM, Yang H, et al. Identification and optimization of pteridinone toll-like receptor 7 (TLR7) agonists for the oral treatment of viral hepatitis. J Med Chem. 2013;56(18):7324-33.

60. Ciancio A, Rizzetto M. Chronic hepatitis D at a standstill: where do we go from here? Nat Rev Gastroenterol Hepatol. 2013. doi:10. 1038/nrgastro.2013.164.

61. Yurdaydin C, Bozkaya H, Onder FO, et al. Treatment of chronic delta hepatitis with lamivudine vs lamivudine+interferon vs interferon. J Viral Hepat. 2008;15:314-21.

62. Yurdaydin C, Bozkaya H, Karaaslan H, et al. A pilot study of 2 years of interferon treatment in patients with chronic delta hepatitis. J Viral Hepat. 2007;14:812-6.

63. Castelnau C, Le Gal F, Ripault MP, et al. Efficacy of peginterferon alpha-2b in chronic hepatitis delta: relevance of quantitative RTPCR for follow-up. Hepatology. 2006;44:728-35. 